\title{
Culture versus Technology: Bridging the Gap to Improve COVID-19 Prevention and Care based on the COVID-19 Task Force Perspectives
}

\author{
Raini Diah Susanti*(D), Neti Juniarti(D), Desy Indra Yani(D), Nurani Nurhasanah \\ Department of Community Health Nursing, Faculty of Nursing, Universitas Padjadjaran, Jatinangor, Indonesia
}

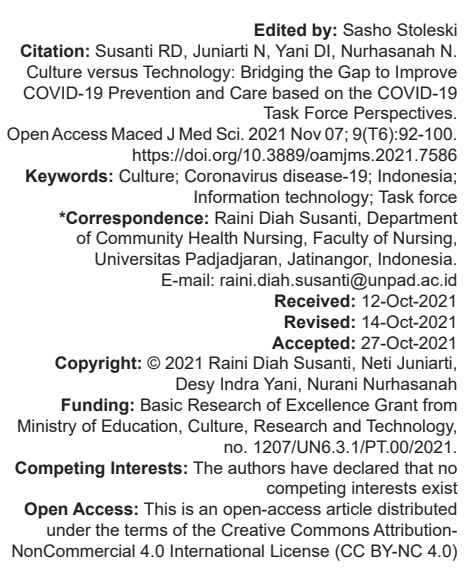

Edited by: Sasho Stoleski Citation: Susanti RD, Juniarti N N Yani Di, Nurhasanah N.
Culture versus Technology: Bridging the Gap to Improve COVID-19 Prevention and Care based on the COVID-19 Task Force Perspectives.
Open Access Maced J Med Sci. 2021 Nov 07; 9(T6):92-100 https://doi.org/10.3889/oamjms.2021.758 Keywords: Culture; Coronavirus disease-19; Indonesia Information technology; Task force *Correspondence: Raini Diah Susanti, Departmen of Community Health Nursing, Faculty of Nursing, E-mail: raini.diah. susanti@unpad ac.id Received: 12-Oct-2021 Revised: 14-Oct-2021 Accepted: $27-0 c t-202$ Copyright: ๑ 2021 Raini Diah Susanti, Neti Juniarti, Desy Indra Yani, Nurani Nurhasanah
Funding: Basic Research of Excellence Grant from Ministry of Education, Culture, Research and Technology, Competing Interests: The authors have declared that no competing interests Open Access: This is an open-access article distributed NonCommercial 4.0 International License (CC BY-NC 4.0)

\begin{abstract}
BACKGROUND: The diversity of Indonesians' cultural backgrounds is a challenge for Indonesia's coronavirus disease (COVID)-19 Task Force efforts to prevent COVID-19. The "infodemic" or misleading information in the community generates both positive and negative responses toward COVID-19.

AIM: The study aims to explore the extent of Indonesia's COVID-19 prevention and care efforts based on the perspective of the COVID-19 Task Force officers, as the frontline in society.

METHODS: This descriptive qualitative study explored the extent of COVID-19 prevention and care based on the perspective of 16 COVID-19 Task Force participants from each region in Sumedang, Indonesia. Data collection was undertaken during the pandemic through semi-structured interviews using telephone $(n=13)$ and face-to-face $(n=3)$ approaches.

RESULTS: Four themes emerged: community sentiment toward COVID-19, origin of COVID-19 in the region, collective cultural activities in local communities, and the use of information and communication technology related to COVID-19.

CONCLUSION: Collaboration with religious leaders and community leaders to integrate the concept of cultural care
\end{abstract} with the use of technology can be developed to improve COVID-19 prevention and care.

\section{Introduction}

On February 11, 2020, the World Health Organization announced the coronavirus disease (COVID-19) caused by the Novel coronavirus (2019-nCov) [1], [2]. Based on data from Indonesia's national COVID-19 Handling Task Force, as of 28 October 2020, there were 400,483 positive cases of COVID-19 in Indonesia, with 13,612 deaths. Of this figure, West Java contributed 35,148 positive cases, and 714 deaths [3]. Given that the number of cases continues to grow every day, the Indonesian government has made various systematic and comprehensive efforts to prevent the broader transmission of COVID-19. However, the government's actions are often hampered by opposing sentiments, including stigmatization in society about the COVID-19 disease [4].

To enhance the handling of COVID-19, including reducing stigmatization, the Indonesian government issued Presidential Regulation Number 82 of 2020 concerning the Committee for Handling the Corona Virus Disease 2019 (COVID-19) and National Economic Recovery, which formed a Task
Force for Handling COVID-19, consisting of various community elements. The task of the COVID-19 Task Force is to implement and control strategic policies, resolve problems and strategic approaches rapidly and precisely, implement strategic guidelines, and implement policies and other necessary steps in the context of enhancing the handling of COVID-19 [5]. Regional governments have formed similar task forces in their provinces and districts to address local crises. Therefore, there are COVID-19 Task Forces in almost every region's district and village, which have a unique role, as they are closest to the community and structured from the bottom-up, directly dealing with the community.

The diversity of the Indonesian people poses a significant challenge for the COVID-19 Task Force, given that cultural background affects psychological response to COVID-19 [4], [6]. In addition, because COVID-19 is a new disease, it has caused an "infodemic" in the community, resulting from the use of information and communication technology [7], [8], [9]. The infodemic confuses the community and generates both positive and negative responses. However, managing the COVID-19 pandemic demands information and 
communication technology in all fields with various obstacles and challenges faced. As such, it is necessary to explore the extent of COVID-19 prevention and care efforts based on the perspective of COVID-19 Task Force officers, as the frontline in society.

\section{Methods}

\section{Research team and reflexivity}

This research was conducted by a team of four researchers with educational backgrounds in community health nursing. The principal researcher was an expert in qualitative and quantitative research in nursing. The principal investigator organized the work within the team to conduct data collection in different areas. The data were compiled by the principal researcher and then transcribed by a member of the research. Two other research members conducted data analysis and reported research results. This report is a collaborative work of all team members.

\section{Study design}

This research was conducted using a descriptive qualitative design with the Leiden ethnosystem approach [10], which uses a historical perspective to depict the prevention and care of COVID-19 based on the COVID-19 Task Forces' views, and field of ethnological study of the Sundanese cultural group.

\section{Participants and settings}

This study used a purposive sample with a snowball technique to obtain data saturation. The inclusion criteria were: COVID-19 Task Force officers working in the area of Sumedang during the pandemic. There were 16 participants from 16 regions with the most significant incidences of COVID-19. These regions represent the Sundanese cultural group, with various geographical and sociodemographic characteristics, located in West Java, Indonesia.

\section{Data collection}

Data collection was undertaken during the pandemic, from July to August 2021, through semi-structured interviews using telephone $(n=13)$ and face-to-face $(\mathrm{n}=3)$ approaches, taking into account health protocols to minimize the transmission of COVID-19. Researchers conducted interviews to explore the perceptions of COVID-19 Task Force officers in preventing and caring for COVID-19 in their respective regions. Interviews were conducted for $30-45 \mathrm{~min}$ in the Indonesian language, starting with explaining the research objectives and obtaining informed consent. The researcher ensured that the data collection process was voluntary and participants could choose not to take part.

\section{Data analysis}

Data analysis employed an interactive analysis method [11]. The interactive analysis occurred in the form of a cycle that compared components of data collection, data reduction, data display, and verification/drawing conclusions. In this analysis cycle, the researchers could continuously move to each component of data reduction, display and verification.

\section{Trustworthiness}

This study devoted attention to credibility through the re-verification of participants to ensure the accuracy of the data. Researchers ensured dependability through data transcription, data reduction, and conclusions. Confirmability was achieved by recording and making field notes systematically. Transferability was achieved by ensuring that participants met the criteria and research objectives, and pay attention to the principles that the data collected is saturated [12], [13]. Thus, data triangulation was undertaken during the interactive cycle until the final stage of verification and concluding. After the data were collected, the data analysis began with data reduction, in the form of selection for simplification and focusing attention from various pieces of information obtained by coding to develop themes. Further, data display to organize and display the configuration of the themes obtained descriptively in the form of a narrative equipped with a schema that the interaction of the components is easy to understand [11]. The final stage was verification or concluding, with meanings explored in-depth to describe the perceptions of the Task Force regarding the prevention and care of COVID-19 in their area.

\section{Ethical considerations}

This research upholds ethical principles. Before conducting data collection, the researcher explained the research objectives to the participants and ensured they had full rights to decide whether to participate in the research voluntarily or refuse to be involved. The researcher guaranteed the confidentiality of the participants' identities by allocating them a code (P1-P16) and protecting the research data through ensuring limited access to a computer system that only the research team could access. The researchers also ensured the safety and wellbeing of the participants, who were treated fairly and equally irrespective of their background. This research received approval 
from the Research Ethics Commission of Universitas Padjadjaran, Bandung number: 474/UN6.KEP/ EC/2021, on June 9, 2021.

\section{Results}

Table 1 presents the characteristics of participants. They had varied ages, were mainly male $(n=12)$ and had higher education backgrounds-both bachelors and masters. Among the participants were nurses $(n=4)$ and midwives $(n=1)$, while the remainder were civil servants who were members of the COVID-19 Task Force in each sub-district. Most of the participants were the Task Force in Chief $(n=9)$ in each region. As many as six people were COVID-19 survivors, so they well understood the situation and condition of people who were confirmed positive for COVID-19.

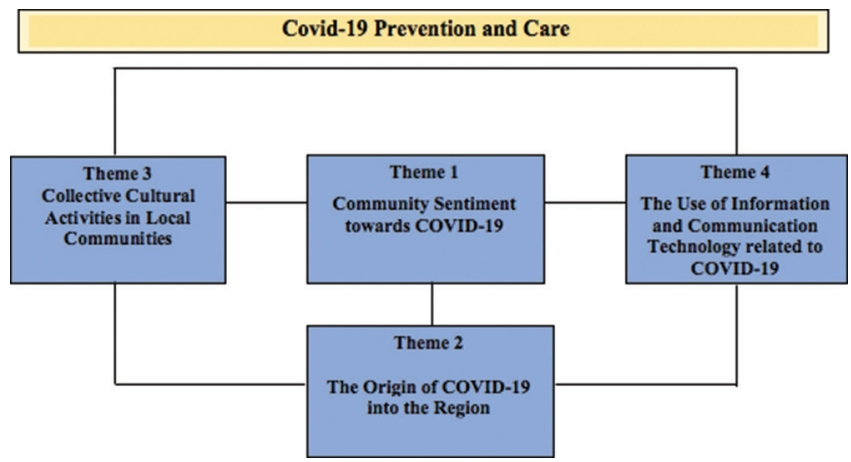

Figure 1: The configuration of finding themes

Figure 1 presents the main themes found in exploring the perceptions of the COVID-19 Task Force officers regarding the prevention and care of COVID-19 in their area. The main themes form a configuration and interact with one another. There were four main themes found in this study: community sentiment toward COVID-19, the origin of COVID-19 in the region, collective cultural activities of local communities that support and hinder the prevention of COVID-19, and the advantages and disadvantages of using information technology and communication in the prevention and care of COVID-19. Each of the main themes was established from several interrelated subthemes and is discussed in the following sections.

\section{COVID-19}

\section{Theme 1: Community sentiment towards}

\section{Belief versus denial}

Several COVID-19 Task Force officers stated that the public's response to COVID-19 varied greatly and was both positive and negative. One Task Force officer who was a COVID-19 survivor stated that they believed in COVID-19 because they had experienced it:

I feel how 10 days-14 days of not being able to smell. $100 \%$ medically, religiously too, right ... this corona year. So sure there is. (P1)

The task force may have to fully trust the research or findings of experts related to COVID-19. (P2)

In contrast, some officers stated that local people did not believe in COVID-19. If not reminded, they sometimes assumed that there was no COVID-19 (P8), as stated by the following participant:

In Ganeas, there are eight villages. Maybe Ganeas is still close to the district city centre, but there are still "Pasisian" areas. That is the culture. So that is sometimes some still do not believe in COVID-trust factor. But relatively small. (P15)

\section{Caring versus ignorant}

The study participants also stated that the local people displayed varied responses to those who were confirmed to have COVID-19. Some people cared about COVID-19 (P2), while others were ignorant or devoted less attention to COVID-19:

Some are concerned, some are scared, some are even apathetic, but not until the rejection occurs. (P10)

Some are indifferent, so sometimes the patient feels that he is not being cared for and shunned. (P3)

Table 1: Characteristics of participants $(n=16)$

\begin{tabular}{|c|c|c|c|c|c|c|c|}
\hline Initials & Age (year) & Gender & Educational level & Position in COVID-19 task force & Length of work as COVID-19 task force & Covid-19 survivor & Region \\
\hline $\mathrm{P} 1$ & 52 & Male & Master & Secretary & 12 months & Yes & Sukasari \\
\hline P2 & 50 & Male & Bachelor & Member & 19 months & No & Cisarua \\
\hline P3 & 42 & Female & Bachelor & Nurse & 19 months & No & Cimalaka \\
\hline P4 & 54 & Female & Master & Chief & 12 months & Yes & Tomo \\
\hline P5 & 53 & Male & Bachelor & Chief & 12 months & No & Cimanggung \\
\hline P6 & 51 & Male & Bachelor & Chief & 19 months & No & Ujung Jaya \\
\hline P7 & 53 & Male & Bachelor & Chief & 12 months & No & Darmaraja \\
\hline P8 & 55 & Male & Bachelor & Chief & 12 months & No & Tanjung Sari \\
\hline P9 & 31 & Female & Bachelor & Midwife & 19 months & Yes & Surian \\
\hline P10 & 55 & Male & Master & Chief & 19 months & No & Rancakalong \\
\hline P11 & 56 & Male & Bachelor & Chief & 12 months & No & Situraja \\
\hline P12 & 56 & Male & Master & Chief & 12 months & No & Jatigede \\
\hline P13 & 36 & Male & Bachelor & Nurse & 19 months & No & Paseh \\
\hline P14 & 53 & Male & Bachelor & Chief & 19 months & Yes & Cisitu \\
\hline P15 & 45 & Male & Bachelor & Nurse & 7 months & Yes & Ganeas \\
\hline P16 & 41 & Female & Bachelor & Nurse & 19 months & Yes & Buahdua \\
\hline
\end{tabular}




\section{Stigma versus support}

Most COVID-19 Task Force officers stated that negative sentiment occurred at the beginning of the pandemic, as people were afraid of contacting COVID-19 (P9, P10 and P13). Local people stigmatized those who were confirmed positive for COVID-19 as disgraceful, shunned and ostracized (P11 and P13). This caused some people to close themselves off and display reluctance to be examined (P16). Some people even rejected family members who were confirmed as having COVID-19:

There was a coincidence that he no longer had a wife, the motorcycle taxi driver ... he turned out to be positive after being checked at the Puskesmas. Now his family does not want to accept him at home to do self-quarantine. But after 14 days, there is still the stigma that people are afraid. (P4)

However, the sentiment of the community towards residents who tested positive for COVID-19 was becoming more conducive (P1). The community provided support and assistance for residents exposed to COVID-19 and in self-quarantine and welcomed the bodies of COVID-19 fatalities to be buried in their community (P5). Moreover, P4 stated that:

Right now, the neighbors are collecting rice donations ["perelek"], goods collected, and then delivered to those who are self-quarantined so the participation of citizens to care. And now the self-quarantine is also good ... the village task force also visits them. (P4)

According to the COVID-19 Task Force, these changes in response occurred because the task force continuously provided information and education regarding COVID-19 to the public (P4, P5 and P6):

We have been educating the community through the village leader at weekly meetings every Tuesday. Being exposed to COVID-19 is not a disgrace, not something we have to treat like HIVIAIDS. Here, it is community cohesiveness, motivating those exposed, even those who died are also welcome, to give money wherever they want to be buried according to the COVID-19 health protocol. (P5)

\section{Theme 2: Origin of COVID-19 in the region}

To understand the perceptions of the COVID-19 Task Force officers in handling COVID-19 in their areas, it is necessary to explore the historical dimensions of the first COVID-19 case in the region. It is essential to understand the cause of the COVID-19 case, based on the perceptions of the COVID-19 Task Force officers. Most of the COVID-19 Task Force officers stated that several factors caused the emergence of COVID-19 in their area, as summarized in the sub-themes below, including high mobility of the community, crowd activities, and lack of compliance with COVID-19 health protocols. The interactions between these sub-themes will help determine problem-solving strategies.

\section{High mobility of people}

Several COVID-19 Task Force officers (P1, P2, P3 and $P 12$ ) stated that there were initially no COVID-19 cases in their area; however, because residents were working in a red zone, there was an explosion of cases:

Why did Sukasari explode? There are seven villages ... one of the villages is called Sukarapih Village, right there is the Griya Jatinangor 1 complex ... that is where the explosion started. So, people from Sukarapih who work in Bandung live here ... much mobilisation. So that also up to five people who died. (P1)

In addition, travellers enter the regions, as there are local tourist destinations (P7 and P12) and offices with employees from outside the region, as stated by the following participant:

Jatigede has become a tourist destination, such as Sunday morning rides activities or several other tourist destinations. Furthermore, there are several government offices and state-owned enterprises whose employees are from outside the city, many immigrants, and community mobility are also quite high. (P12)

\section{Crowd activities}

In terms of high physical mobility, the emergence of COVID-19 in the region was also due to community activities in crowds. Crowds cause close physical contact between people, such as when visiting a market or hospital, undertaking family activities, and attending weddings (P4 and P14). All these activities are related to the local culture, as stated by the following COVID-19 Task Force officer:

Ujungjaya and Indramayu have always been in the red zone, so, most of the time, they are exposed to shopping at the market, to hospitals in Majalengka. So Ujungjaya contracted the COVID from an outside district. (P6)

\section{Lack of compliance with health protocols}

Alongside high mobility and crowd activity, the emergence of COVID-19 cases is attributed to poor compliance with health protocols, such as wearing masks, which is understandably in the village areas (P4). Lack of compliance is also influenced by negative sentiment and the belief that COVID-19 is not real, causing people to ignore health protocols (P15). As stated by the following participant:

Provincial roads pass Cimalaka, and there are many public transportation routes; many immigrants are also the entrance and exit 
for many people. Incidentally, not all people have obeyed the protocols, so the spread of COVID is not alarming, especially in the last month. However, the first horrendous case was when a security guard at one of the malls in Sumedang, who happened to be a Cimalaka person, was confirmed positive for COVID. (P3)

\section{Theme 3: Collective cultural activities in local communities}

Several participants stated that the community structure in their region was still rural, with most of the population working in the agricultural and plantation sectors (P12 and P14):

The culture, God willing, still carries the culture of local wisdom. Hence, the culture of mutual cooperation and obedience to the government still exists. The patriarchal culture is still strong. When there are government appeals, like most rural structures, it is still not like urban people ... Yes, most of them are critical in cities, but most of them are less critical here. (P14)

\section{of COVID-19}

Cultural activities that support the prevention

As previously explained, local communities still adhere to traditional local wisdom in their daily lives. Among these cultural-related activities is the culture of gotong-royong or providing mutual assistance to fellow citizens. This was undertaken during the COVID19 pandemic, with some people assisting residents in self-quarantine because of exposure to COVID-19 or testing positive for COVID-19:

If there are self-quarantined people in the village, they help each other ... "sasieureun sabenyeureun" [a little bit]. Do not let the selfquarantined resident [be] neglected. (P7)

The assistance provided usually comprised essential food items, such as rice and vegetables; goods; or money. This activity was undertaken voluntarily based on community initiatives, and managed independently.

\section{COVID-19 \\ Cultural activities that hinder the handling of}

Collective culture in local communities could also be an obstacle to handling COVID-19 because cultural activities are undertaken in crowds, posing a high risk of COVID-19 transmission. These activities are also contrary to the COVID-19 prevention health protocols. These activities include parties, wedding celebrations, religious activities, congregational prayers, recitations related to death, tahlilan (communal prayers), joint activities with families and group prayers for deceased relatives. Another death ritual, nyusur taneuh, is undertaken by local people according to their beliefs and involves many people, as revealed in the following statement:

The first incident was in Linggajaya. His son went on vacation to Bekasi, then the next day he got married, the next day he got married again. Died husband and wife. We also find it difficult to change culture, even if it can be gradual. For example, there is "tahlilan," there is a land survey, right? But now, for example, there is "tahlilan" in the mosque, and walking along the land as soon as the body was buried, then the family continued to gather to pray. So the first day here is not "tahlilan," but "nyusur taneuh" along the ground. So I do not know what philosophy is like. What is clear is that, according to the culture in the village, the term is exploring the land. If you do not do it, your soul will not stay. So what makes it challenging to handle COVID-19 is sometimes cultures such as marriage. (P14)

\section{Theme 4: Use of information and communication technology related to COVID-19}

Some participants stated that there were positives and negatives to using information and communication technology to manage COVID-19, and stated that it is more effective to communicate directly in the field, face-to-face (P11). The following are two subthemes of the advantages and disadvantages of using information and communication technology to handle COVID-19 in Sumedang, based on the perspectives of the COVID-19 Task Force officers.

\section{Advantages of using information and communication technology}

Most of the Sumedang areas have good internet access, which allowed the local government to launch the Wa Kepo application (WhatsApp for online service information in Sumedang Regency). This app was provided to help the community access information services, primarily related to COVID-19 and vaccination registration (P1, $\mathrm{P} 2, \mathrm{P} 3$ and $\mathrm{P} 6)$.

It is beneficial because direct socialisation is not possible and will drain energy as well. With social media, it is easier for us. (P10)

This app was supported by public awareness of technology or technology literacy, although this awareness is not evenly distributed among all ages (P15). Likewise, supporting facilities for the use of information and communication technology, such as fiber optics, are being prepared by the government (P12 and P14) as stated by several participants-for example:

Certain areas have good reception of internet access, but other areas are not easy to get 
internet access. Nevertheless, there is a program from the Ministry of Communication and Informatics that includes installing optical cables. Yes, next year, it looks like the Regent's program will be affordable for all villages. So it is possible. Because the presence of every village even via cell-phone. So, Sumedang as a digital region can be realised. Although there may be certain obstacles, that is not a reason for not making the program successful. (P12)

\section{technology}

\section{Limited use of information and communication}

However, the ongoing use of technology and information has limitations and perceived challenges, especially with the proliferation of irresponsible information (the "infodemic"), which can hinder the implementation of government programs, particularly the COVID-19 control program. Thus, the participants stated that the infodemic needs to be balanced by official and valid information from the government (P2). In addition, several participants stated that certain areas are blind spots that have been unable to access information online (P11, P12, P15 and P16). Some people, especially those aged 45 years old and over, are still lacking in technology proficiency (P15). Moreover, the majority of people who work as farmers or gardeners require that every activity be performed in the afternoon after they have finished working in the fields or gardens (P15 and P16). For example:

As for technology literacy, there are more teenagers and adults. For those under 40, maybe the technology is already familiar. For ages 45 and over, it is still tricky-especially the village of Dayeuh sublime. There is an area for the commander of the signal, and it is challenging. If there, Telkomsel is also no reception. There are eight villages in Ganeas. Maybe Ganeas is still close to the district city centre, but there are still uptown areas. That is the culture. So ... sometimes they still do not believe in COVID-trust factor. But relatively small. For vaccines ... lately, thank God, people are enthusiastic to get the vaccination. In some areas, where most of the farmers [are] inhabitants, the vaccination [centre] is running until the afternoon, after the farmers return from the fieldwork. (P15)

\section{Discussion}

The results of the data analysis indicated four main themes related to the perceptions of the COVID-19 Task Force officers regarding the prevention and treatment of COVID-19 in their area. The four main themes were the origin of COVID-19 in the region, community sentiment toward COVID-19, collective cultural activities of local communities, and the use of information and communication technology related to COVID-19.

\section{Community sentiments on COVID-19}

People have different responses to COVID-19, with the participants describing both positive and negative sentiments. Negative sentiments mainly occurred in the early days of the pandemic as the psychological effects were felt by individuals, such as feelings of fear, anxiety, stress, and doubt [4], [9], [14], [15]. In addition, the infodemic created confusion in the community and lack of knowledge about COVID-19 triggered stigma [7], [9], [16]. Thus, suitable health education is required for the community to increase knowledge, attitudes and behaviors that support COVID-19 prevention [14]. Such education is essential because knowledge has a significant relationship with behavior [17], [18].

People who have a common understanding of the COVID-19 disease affect their perspective on the disease, especially among groups who deny the existence of COVID-19. This distrust or ignorance of COVID-19 causes uncooperative behavior in adhering to the recommended health protocols [19], [20], [21], [22], [23]. Another negative sentiment identified in this study is stigma or negative attributes toward people exposed to or confirmed positive with COVID-19. Stigma toward COVID-19 also occurs because, as a new disease, many factors are unknown and require further research. This finding aligns with Trejos-Herrera et al., who found that stigma will cause people to close themselves off and refuse treatment or medication because of shame [21]. Bruns et al. also stated that more extreme stigma will result in violent behavior toward a person or group of people, which can include gossip, discrimination and exclusion of people exposed to or confirmed positive for COVID-19 [22].

However, the COVID-19 Task Force also revealed positive public sentiment toward COVID-19, as demonstrated by supportive attitudes and behavior, and vice versa with the negative sentiment response described previously. The community provided support to residents exposed to and confirmed positive for COVID-19 during self-quarantine by assisting in the form of food, goods or money. This aligned with the enhanced public insight achieved through campaigns, socialization and education from the COVID-19 Task Force. The negative sentiment of the community shifted toward positive sentiment [14], [17]. In addition, the local community had a collective cultural character to help others in trouble, as expressed by the participants.

\section{Origin of COVID-19 in the region}

Exploring the historical dimensions of the first COVID-19 case in an area is essential to determine the 
cause of COVID-19 spread. Thus, it is possible to identify the interaction relationships of the themes helpful in setting problem-solving strategies [11]. The study results indicated that COVID-19 originated in Wuhan, China [24] until entrance to the Sumedang area was caused by the high mobility of people among places outside the region, both commuters and migrants. Moreover, activities in crowded places, such as markets, hospitals, tourist attractions and events, entail a high risk of COVID-19 transmission due to social interaction. In addition, the community has demonstrated weak compliance in implementing health protocols, such as hand washing, wearing masks and maintaining distance [25]. These results indicate interaction between Theme 1 (origin of COVID-19 in the region) and Theme 2 (negative public sentiments related to COVID-19), leading to ignoring the COVID-19 prevention health protocols. It is an obstacle for health workers in the COVID-19 task force in enhancing the handling of COVID-19 in the Sumedang area. Therefore, the recommendation to stay at home, implement social restrictions, place restrictions on community activities, and isolate is one solution to prevent community mobilization [26], [27].

\section{communities \\ Collective cultural activities in local}

This study found that the local community, as part of the Sundanese cultural group, still maintains local wisdom, and the Sundanese belief system and way of life influence health behavior [28], [29], [30]. The Sundanese way of life and way of thinking aim to maintain a balance that they believe exists in the universe [31]. Various ceremonies and magical actions maintain this balance. Meanwhile, social balance is maintained during parties, celebrations and rituals in daily life by upholding the principles of mutual or reciprocal, silih asah, silih asih, and silih asuh [28], [32]. Collective cultural activities in the form of parties and rituals at every phase of life (pregnancy, childbirth, teenage years, marriage and death) are undertaken, and involve many people. If viewed from the security aspect during the COVID-19 pandemic, these activities have high risk of transmitting the COVID-19 virus because they create crowds, close contact and lack of social distancing [25]. This study's participants stated that this cultural activity was one of the causes of the emergence of COVID-19 in the local area. One of the inhibiting factors in the acceleration of COVID-19 as stated by the COVID-19 Task Force participants. Thus, it is not easy to separate religion from a belief system because some Sundanese still practice both [30]. This occurs mainly in rural communities, where the boundary between religious and non-religious elements is not recognized. Elements of religion and original belief, or adat-istiadat, seem to have been integrated into one belief system and are responded to with the same emotion [31].

However, silih asah means giving experience and knowledge to each other, that one's shortcomings are added to by others, and that fellow community members correct each other's mistakes. Silih asih means loving each other, and silih asuh means guiding each other [29]. This study found that the culture of gotong royong-in which groups and community initiatives collect food and money to help residents exposed to COVID-19 and in self-quarantine-is still attached to the local community. This demonstrates that collective culture involves concern for others and can reduce negative sentiment or stigmatization in people exposed to or testing positive for COVID-19. Lubis found that religious life is often influenced by belief in spirits and magical powers [32], and the concept of health in the Sundanese community refers to physical and spiritual health. Sundanese hold the view that physical and spiritual satisfactions are equally important and closely related. Physical things are always stated concerning the spiritual, and vice versa [28], [29], [30], [31]. The Sundanese have health behavior patterns in the form of health promotion, disease prevention, and healing and recovery in all matters [28]. Thus, cultural activities that support efforts to deal with COVID-19 can be maintained, while cultural activities that hinder the handling of COVID-19 should be negotiated or modified to avoid increased transmission of COVID-19. As stated by Leininger [33] and Soemardjo [31], change is a necessity, and no culture remains unchanged.

\section{Use of information and communication technology related to COVID-19}

The COVID-19 pandemic forced humans to use information and communication technology or digital technology to minimize contact with the COVID-19 virus. Various digital technologies, cellular phones, social media apps, and social media platforms were used for all service purposes through remote and contactless methods. This study revealed that an online information service app was provided by the local government and well received by the community. In addition, good internet access in most areas, technology-literate people, and positive responses from health workers and the COVID-19 task force minimized physical and energy contact compared with offline. Through this app, the public can obtain valid information about the prevention and handling of COVID-19, including information on COVID-19 vaccinations.

However, the results of data analysis indicated that some areas are blind spots or do not have internet access. Thus, some people cannot access online information services provided by local governments. In addition, some people in the age group of 45 years and over lack technology literacy, so there is a gap in accessing the information needed via online services. Currently, the government is preparing fiber optics to reach blind spot areas, so that internet access is evenly distributed throughout the region. However, several COVID-19 Task Force officers revealed that, although there are online information service applications, door-to-door and face-to-face interactions with the 
public - especially residents who are in self-quarantineare most effective. Considering the various barriers and limitations caused by cultural activities and the use of technology in society, it is necessary to consider how to bridge the gap to improve efforts to prevent and care for COVID-19. Several factors must be considered regarding the wise use of digital technology, as follows:

1. Values and governance, including the extent to which digital technology policies align with the values held by society

2. Access, including considering communities and managers who experience limited access

3. Security and welfare, including which risk assessment is used to review the use of digital online technology

4. Knowledge and skills, including whether communities and officers will be provided training in the use of digital technology

5. Participation, including the role of each element of digital technology users

6. Cultural care patterns, including cultural care preservation, cultural care accommodation, cultural care re-patterns, and new cultural care practices [33], [34], [35].

\section{Conclusion}

The Indonesian COVID-19 Task Force has played a vital role in the success of COVID-19 prevention and care, in collaboration with cross-sectors. Understanding the perceptions and experiences of the COVID-19 task force in terms of prevention and care of COVID-19 is essential to develop a planning strategy, as indicated by the findings of this study. This study revealed that there is a gap between the collective cultural activities of the local community and the use of information and communication technology, which interact in the prevention and care of COVID-19. Nurses should collaborate with religious leaders and community leaders to integrate cultural care with the appropriate use of technology, so that local communities can access information and services through technology to fill this gap. This strategy should align with the local culture, so the community can undertake cultural activities by wisely using information and communication technology, without ignoring the COVID-19 prevention health protocols. Implementing this strategy will reduce the risk of COVID-19 transmission.

\section{References}

1. Lai CC, Shih TP, Ko WC, Tang HJ, Hsueh PR. Severe acute respiratory syndrome Coronavirus 2 (SARS-CoV-2) and
Coronavirus disease-2019 (COVID-19): The epidemic and the challenges. Int J Antimicrob Agents. 2020;55(3):105924. https:// doi.org/10.1016/j.ijantimicag.2020.105924

PMid:32081636

2. World Health Organization. Novel Coronavirus (2019-nCoV) Situation Report. Geneva: World Health Organization; 2020. p. 1-7, 2020. Available from: https://www.who.int/docs/defaultsource/coronaviruse/situation-reports/20200211-sitrep-22ncov.pdf?sfvrsn=fb6d49b1_2. [Last accessed on 2021 Sep 12].

3. Satuan Tugas COVID-19 [Covid-19 Task Force], Peta Sebaran COVID-19 di Indonesia [Map of the distribution of COVID-19 in Indonesia]; 2020

4. Janitra FE, Melastuti E, Yusuf AH, Fadhilah H, Wibawa YA Perceived stigma, psychological response, and nurse coping in the COVID-19 pandemic in Indonesia. J Keperawatan Padjadjaran. 2021;9(1):10-7. https://doi.org/10.24198/jkp. v9i1.1561

5. Negara KS. Peraturan Presiden R.I No. 82 Tahun 2020, Indonesia; 2020.

6. Manik MJ, Natalia S, Theresia T. Social stigma towards nurses taking care of patients with COVID-19 in Indonesia: A mixedmethods study. Belitung Nurs J. 2021;7(2):98-106. https://doi. org/10.33546/bnj.1322

7. Kulkarni P, Prabhu S, Kumar S, Ramraj B. COVID-19-infodemic overtaking pandemic? Time to disseminate facts over fear. Indian J Community Health. 2020;32(2):264-8. https://doi. org/10.47203/ijch.2020.v32i02supp.018

8. Karasneh R, Al-Azzam S, Muflih S, Soudah O, Hawamdeh S, Khader Y. Media's effect on shaping knowledge, awareness risk perceptions and communication practices of pandemic COVID-19 among pharmacists. Res Social Adm Pharm. 2021;17(1):1897-902. https://doi.org/10.1016/j. sapharm.2020.04.027 PMid:32340892

9. Islam A, Pakrashi D, Vlassopoulos M, Wang LC. Stigma and misconceptions in the time of the COVID-19 pandemic: A field experiment in India. Soc Sci Med. 2021;278:113966. https://doi. org/10.1016/j.socscimed.2021.113966

PMid:33940435

10. Leendert LJ, Slikkerveer J, Brokensha DW, Dechering W, Warren DM. The Cultural Dimension of Development: Indigenous Knowledge Systems. London: Intermediate Technology Publications; 1995.

11. Miles MB, Huberman AM, Saldaña J. Qualitative Data Analysis: A Methods sourcebook, Third; 2014.

12. Lincoln EG, Guba YS. Naturalistic Inquiry. New York, United States: SAGE Publications Inc.; 1985.

13. Polit C, Beck DF. Nursing Research: Generating and Assessing Evidence for Nursing Practice. $10^{\text {th }}$ ed. Philadelphia, PA: Wolters Kluwer Health; 2017.

14. Azlan AA, Hamzah MR, Sern TJ, Ayub SH, Mohamad E. Public knowledge, attitudes and practices towards COVID-19: A crosssectional study in Malaysia. PLoS One. 2020;15(5):e0233668. https://doi.org/10.1371/journal.pone.0233668 PMid:32437434

15. Widiasih R, Ermiati E, Emaliyawati E, Hendrawati S, Susanti RD, Sutini T. Nurses' feelings and perspectives of the COVID-19 pandemic: A qualitative study in a developing country. Open Access Maced J Med Sci. 2021;9(G):71-80.

16. Islam MS, Sarkar T, Khan SH, Mostofa Kamal AH, Hasan SM, Kabir A, et al. COVID-19-Related infodemic and its impact on public health: A global social media analysis. Am J Trop Med Hyg. 2020;103(4):1621-9. https://doi.org/10.4269/ajtmh.20-0812 PMid:32783794

17. Widiasih R, Ermiati E, Emaliyawati E, Hendrawati S, Susanti RD 
Sutini T, et al. Nurses' actions to protect their families from COVID19:Adescriptivequalitative study. Glob Qual Nurs Res. 2021;8:1-8. https://doi. org/10.1177/23333936211014851

\section{PMid:33997120}

18. Juniarti N, Zannettino L, Fuller J, Grant J. Improving community nursing care services through the academic nursing centre model. Aust Nurs Midwifery J. 2015;23(6):39. PMid:26863717

19. Villa S, Jaramillo E, Mangioni D, Bandera A, Gori A, Raviglione MC. Stigma at the time of the COVID-19 pandemic. Clin Microbiol Infect. 2020;26(11):1450-2. https://doi. org/10.1016/j.cmi.2020.08.001 PMid:32777361

20. Trejos-Herrera AM, Vinaccia S, Bahamón MJ. Coronavirus in Colombia: Stigma and quarantine. J Glob Health. 2020;10(2):020372. https://doi.org/10.7189/jogh.10.020372 PMid:33110564

21. Bruns DP, Kraguljac NV, Bruns TR. COVID-19: Facts, cultural considerations, and risk of stigmatization. J Transcult Nurs. 2020;31(4):326-32. https://doi.org/10.1177/1043659620917724 PMid:32316872

22. Pan SW, Shen GC, Liu C, Hsi JH. Coronavirus stigmatization and psychological distress among Asians in the United States. Ethn Health. 2021;26(1):110-25. https://doi.org/10.1080/135578 58.2020 .1849570 PMid 33307773

23. Akbar A, Juniarti N, Yamin A. The roles of community health nurses' in COVID-19 management in Indonesia: A qualitative study. IJCBNM. 2021;2-15:1-14. https://doi.org/10.30476/ ljcbnm.2021.90884.1739.2

24. World Health Organization. Novel Coronavirus (2019-nCoV) Situation Report. Geneva: World Health Organization; 2020.

25. World Health Organization Europe (WHO Europe). Transmission of SARS-CoV-2: Implications for Infection Prevention Precautions, Scientific Brief; 2020. p. 1-10. Available from: https://www.who.int/news-room/commentaries/ detail/transmission-of-sars-cov-2-implications-for-infectionprevention-precautions $\% 0$ Ahttps://bityli.com/j84ms. [Last accessed on 2021 Aug 09].
26. Williams SN, Armitage CJ, Tampe T, Dienes K. Public perceptions and experiences of social distancing and social isolation during the COVID-19 pandemic: A UK-based focus group study. BMJ Open. 2020;10(7):e039334. https://doi.org/10.1136/bmjopen-2020-039334

PMid:32690752

27. Amirudin A, Urbański M, Saputra J, Johansyah MD, Latip L, Tarmizi A, et al. The impact of the covid-19 self-isolation policy on the occupations of vulnerable groups. Int $\mathrm{J}$ Environ Res Public Health. 2021;18(12):6452. https://doi.org/10.3390/ ijerph18126452

PMid:34203631

28. Erwina W. Iber Kesehatan in Tatar Sunda, Indonesia: Utilisation of Traditional and Modern Health Information and Communication System in Sukamiskin, Bandung. Leiden: Universiteit Leiden; 2019.

29. Saefullah K. Gintingan in Subang: An Indigenous Institution for Sustainable Community based Development in the Sunda Region of West Java, Indonesia. Leiden: Universiteit Leiden; 2019.

30. Garna J. Budaya Sunda: Melintasi Waktu Menantang Masa Depan [Sundanese Culture: Across the Time Challenging the Future]. Bandung: Unpad Research Institute and Judistira Garna Foundation; 2008.

31. Soemardjo J. Sunda Pola Rasionalitas Budaya [Sunda Patterns of Cultural Rationality]. Bandung: Kelir Publishers; 2011.

32. Lubis N. Tradisi dan Transformasi Sejarah Sunda [Sundanese Tradition and Historical Transformation]. Bandung: Adikarya IKAPI Foundation and the Ford Foundation; 2000.

33. Leininger M. Culture care theory: A major contribution to advance transcultural nursing knowledge and practices. J Transcult Nurs. 2020;13(3):189-92. https://doi.org/10.1177/10459602013003005 PMid: 12113148

34. Grant B, Manning A, Thurman C. Digitally Kind; 2021. p. 1-54.

35. Lukman M, Ibrahim K, Yani DI, Sari SP, Juniarti N. Exploring strategies to improve the performance of community health volunteers for tuberculosis care and prevention: A qualitative study. Int J Community Based Nurs Midwifery. 2019;7(4):270-8. https://doi.org/10.30476/IJCBNM.2019.81353.0 PMid:31641676 